\title{
MODERN ANIMAL PRODUCTION AND ANIMAL WELFARE
}

Eugeniusz Herbut

Institute of Animal Production, National Research Institute in Balice, Krakow, Poland

Corresponding author: e-mail: eugeniusz.herbut@izoo.krakow.pl

\begin{tabular}{|c|c|}
\hline ARTICLE INFO & ABSTRACT \\
\hline $\begin{array}{l}\text { Article history: } \\
\text { Received: April } 2018 \\
\text { Received in the revised form: } \\
\text { June } 2018 \\
\text { Accepted: August } 2018 \\
\end{array}$ & \multirow{2}{*}{$\begin{array}{l}\text { The aim of the paper is to discuss the links between modern livestock } \\
\text { production, including its techniques and concentration, with animal } \\
\text { welfare requirements. Modern livestock production is related to } \\
\text { modern facilities, precise livestock production, as well as intensive } \\
\text { and high stocking density. At the same time, it requires providing the } \\
\text { animals with minimal living conditions, i.e. the welfare set out in the } \\
\text { relevant regulations. This in turn should guarantee a good quality of } \\
\text { raw livestock materials and products. }\end{array}$} \\
\hline $\begin{array}{l}\text { Key words: } \\
\text { modern animal production, } \\
\text { well-being, } \\
\text { technical equipment, } \\
\text { quality }\end{array}$ & \\
\hline
\end{tabular}

\section{Introduction}

In recent years, there has been a huge progress in modern animal production technologies. It is related not only to the modern facilities, but also to their technical equipment, which together translate into animal welfare (Herbut and Walczak, 2017, Angrecka and Herbut, 2017). Modern livestock production is related to modern facilities, precise production techniques and intensive stocking density. It also uses renewable energy sources (Bartkowiak et al., 2012, Michałek and Grotkiewicz, 2010). Livestock welfare is already a well-established issue in the animal and veterinary sciences, agricultural engineering and production practice. It is the result of providing the animals with the basic keep needs: feed, access to water, living space, technical equipment, hygiene and proper living conditions. The concept of animal welfare has been well integrated into our vocabulary and consciousness, especially that of animal husbandry specialists, veterinary surgeons, engineers and producers. Its practical realization is less noticeable, however (Herbut and Walczak, 2008; 2017).

The scientific approach to the issue of animal welfare is of great importance, as it requires interdisciplinary engagement of researchers from various fields and disciplines: agricultural engineering, animal husbandry, biology, physiology, veterinary science, ethology, animal psychology or bioethics (Bessei, 2018; Lund et al., 2006; Michałek , 2007).

According to a survey conducted by the Eurobarometer (2016), nearly half of Europeans $(46 \%)$ relate welfare to the obligation to protect all animals. A slightly smaller percentage, approx. $40 \%$, associate welfare only with farm animals in terms of their keep, and providing them with better conditions; in Poland, these proportions are respectively 33 and $30 \%$. Interestingly, the percentage of citizens who perceive animal welfare as more than 
just protection (i.e. with regard to minimum living conditions) is $18 \%$ in the European Union and $14 \%$ in Poland. This result is very close to that, in which welfare is considered synonymous with protection, i.e. $17 \%$ both in the Union and in Poland. A similar percentage of respondents recognize that animal welfare contributes to obtaining better quality of animal materials and products (17\% EU, $12 \%$ Poland). The vast majority of Europeans ( $94 \%$ in the EU and $86 \%$ in Poland) believe that the welfare of farm animals should be protected. Over half of respondents in the EU ( $(57 \%, 36 \%$ in Poland) consider this to be "very important" and $37 \%$ as "rather important" (52\% in Poland). Only a small percentage of the respondents ( $4 \% \mathrm{EU}, 7 \%$ Poland) do not recognize animal welfare as a significant issue. Nevertheless, despite the number, awareness-raising activities should be carried on More than four out of five ( $82 \%$ ) of respondents in the EU (77\% in Poland) believe that the level of animal welfare should be higher than at present. Almost two-thirds (64\%) of Europeans (59\% of Poles) indicated that they would like to receive more information about animal husbandry conditions in their country. Europeans strongly argue that products imported from outside the EU should meet the same animal welfare standards as those in force in the EU (93\%). Following this line of thought, nine out of ten respondents $(90 \%)$ agree than worldwide animal welfare standards should be established. Overall, $59 \%$ of EU residents (44\% of Poles) declare that they are willing to pay more for animal materials and products coming from animal-friendly living conditions, being aware of the costs. $35 \%$ of them (27\% in Poland) are willing to pay up to 5\% more, and $16 \%$ (both in EU and in Poland) from 6 to $10 \%$ more. It should be noted that when buying products, over a half of EU citizens $((52 \%, 41 \%$ of Poles) look for labels that identify animal welfare during farming. In addition, $47 \%$ of Europeans (37\% of Poles) declare that the selection of animal products coming from livestock kept in animal-friendly conditions, offered by stores and supermarkets, is insufficient and should be significantly increased. The aim of the paper is to discuss the general links between modern livestock production, including its techniques and concentration, with animal welfare requirements.

\section{Legal regulations}

Welfare is associated with requirements relating to animal keeping standards, which specify only the minimum conditions required to ensure a basic level of welfare. In the European Union, there are over 80 different types of legal acts related to animal keeping in the form of directives and regulations. In Poland, their direct equivalent is the Animal Protection Act of 30 July 2013 and the Regulation of the Minister of Agriculture and Rural Development of 28 June 2010 on minimum conditions for keeping livestock species. Please note that before the first animal protection act was adopted in 1997, the binding law in this respect was a decree of the President of the Republic of Poland from 1925, although a very progressive one at the time. The reform of the EU's Common Agricultural Policy, implemented since 2005, also introduced regulations known as the minimum cross-compliance requirements. The scope of cross-compliance covers, among others, three areas. These are: environmental protection and animal identification and registration; public health of people, as well as animal and plant health; animal welfare. While the requirements for the identification and registration of animals have been in force since 2009, and for animal health since 2011, animal welfare requirements have been in force only from 2013. They are 
Modern animal production ...

overseen by the Veterinary Inspectorate. The latter are included in the Regulation and Public Notice of the Ministry of Agriculture and Rural Development of December 15, 2016 amending the list of requirements set out in EU regulations. According to the data of the Ministry of Agriculture and Rural Development, inspections of animal farms showed only a few percent share of shortcomings, mainly incorrect labelling or lack of veterinary documentation. The scope related to animal welfare includes, among others: care and supervision of animals; veterinary documentation; freedom of movement; harmlessness of materials and devices; microclimate, proper ventilation and lighting for animals; hygiene of rooms and equipment; access to water and feed (Budzyńska, 2015).

Please note that although the current scope of control of animal welfare requirements does not cover all the issues contained in the aforementioned regulations, many animal producers and breeders are critical of them. The most discussion was raised by the implementation of EU directives on the conditions of keeping laying hens and broiler chickens. The main reason for this position is the requirement of considerable investments to implement required changes in technical equipment in the rooms.

\section{Requirements for animals}

Over the last several decades, the strive to improve the economic efficiency of animal production led to the introduction of intensive technologies of livestock production, e.g. open, non-stresses cowsheds. They are related to a large concentration of animals in a single place, hence the facilities that were built for livestock served more the purpose of man's comfort rather than of the animals themselves. Today, we know that these systems essentially impact not only the behavior of the animal (e.g. twice-daily milking), but also the physiology of its organism, thus affecting the quantity and quality of obtained materials and products (Herbut and Walczak, 2017). Experience and observations have shown that in the classically used keep systems the level of animal welfare decreases along with the intensification of production (Botreau et al., 2007; Herbut, 2012). The behavior of animals expresses not only their well-being, but also their response as a living organism to the provided environmental conditions. In other words, it is a sign language, in which animals express their opinion, hence the animals' reaction to an arranged and prepared facility, as well as its technical equipment needs to be observed. This applies not only to the fulfillment of minimum, but above all, above-average requirements. This is the subject of extensive research work carried out at the Institute of Animal Production of the National Research Institute. The results are expected to lead to achieving not only a higher quality, especially of animal materials and products, but also of comfort for the animals. On the other hand, in a chain store, such a product should be appropriately marked as produced with a technology marked by an increased level of animal welfare. In fact, some retail chains have already started doing just that.

Improvement of breeding value of animals should be followed by improvement of welfare, implemented through modern facilities and their technical equipment. The welfare of animals is influenced by: the human factor, i.e. the handling of animals; keeping conditions; stocking per unit area and adaptive behavior of animals. However, it should be emphasized that the living conditions are the factor with the highest expression. 
Human influence on environmental conditions, health and productivity of animals can be divided into direct and indirect impact. The direct impact includes: handling, daily work related to breeding and care, and the color of protective clothing. Animal handlers should be calm, gentle, conscientious and reliable, as well as a knowledgeable of the ethological issues of animals. Daily work related to keeping and care should be carried out regularly, at specific times of the day, calmly and gently, with no excessive rush and sudden movements causing anxiety, nervousness and startling of the herd. In indirect impact, man is the leading environmental factor. It is on his will, skills, character traits and education that the system of other factors depends to a large extent. Man affects animals and their production and health by: deciding on the type of animal exploitation; making a decision on microclimatic conditions in the facility; maintaining hygiene in the facility; making a decision on the method of feeding and watering, or determining the quality and quantity of feed, along with access to it. Man must ensure that keeping the animals using a selected technology is in accordance with their physiological requirements (Herbut and Walczak, 2008; 2017).

\section{Selected requirements for facilities}

As Herbut and Walczak (2017) note, European Certification Systems assume an increase of at least $20 \%$ or even $40 \%$ of space available for pigs; use of straw bedding; limiting the number of days in yokes for sows subject to insemination to 4 days; natural lighting; air conditioning; access to pens and maximum transport distance up to $200 \mathrm{~km}$. This places high demands on animal facility design, both general and interior, together with technical equipment. Hence, large-scale farms are characterized by: high production capacity; animal concentration; a closed and continuous production process ensuring uniformity and rhythm, along with the management of manure (Romaniuk and Karbowy, 2008). They enable good management and specialization of animal production units at low own costs. In addition, production processes in large-scale farms are highly mechanized and automated, using the latest developments in science and technology. They ensure food security and biosafety, together with protection of the natural environment (Krupiński et al., 2011). They contribute to the development of rural areas. One can't, however, lose sight of the need to ensure a high level of animal welfare and the important human-animal relationship, which is important in both small and large concentration, as well as density of animals.

\section{Conclusion}

Modern animal husbandry and breeding is associated with modern facilities, precise production techniques, as well as intensive stocking density. This must be closely related to providing the animals with minimum living conditions, which provide them with a basic level of welfare. The latter should guarantee good quality of obtained animal materials and products. 
Modern animal production ...

\section{References}

Angrecka, S., Herbut, P. (2017). Eligibility of lying boxes at different levels in a freestall barn. Annals of Animal Science, Vol. 17, No. 1, 257-269.

Bartkowiak, A., Namyślak, Ł., Mielcarek, P. (2012). Działania strategiczne w zakresie dobrostanu zwierząt jako element zrównoważonego rozwoju rolnictwa. Problemy Inżynierii Rolniczej. Vol.1 (75), 99-104.

Bessei, W. (2018). Impact of animal welfare on worldwide poultry production. World's Poultry Science Journal, Vol. 74, no. 2; 211-224.

Botreau, R., Veissier, J., Butterworth, A., Bracke, M., Keeling, L. (2007). Definition of criteria for overall assessment of animal welfare. Animal Welfare, 16, 225-228.

Budzyńska, M. (2015). Współczesne zagadnienia w badaniach i nauczaniu dobrostanu zwierząt Wiadomości Zootechniczne, 1, 58-64.

Eurobarometr, (2016). Attitudes of Europeans towards Animal Welfare. Report. 86.

Herbut, E., Walczak, J. (2008). Importance of extensive animal production in Poland. Annals of Animal Science, Vol. 8, no. 3, 3-15.

Herbut, E., Walczak, J. (2017). Dobrostan zwierząt w nowoczesnej produkcji. Przegląd Hodowlany, 5, 3-7.

Herbut, E. (2012). Innowacyjność w ekologicznej produkcji zwierzęcej. Inżynieria Rolnicza. no. 2 , Vol.1, 73-77.

Krupiński, J., Horbańczuk, J.O., Kołacz, R., Litwińczuk, Z., Niemiec, J., Zięcik, A. (2011). Strategiczne kierunki rozwoju produkcji zwierzęcej uwarunkowane oczekiwaniem społecznym, ochroną środowiska i dobrostanem zwierząt. Polish Journal of Agronomy, 7, 59-67.

Lund, V., Coleman, G., Gunnarsson, S., Appleby, M.C., Carkinen, K. (2006). Animal welfare science-Working at the interface between the natural and social sciences. Behaviour Science, Vol. 97, 37-49.

Michałek, R. (2007). Inżynieria rolnicza-stan obecny i szanse rozwoju. Inżynieria Rolnicza, No. 1 (99), 7-14

Michałek, R., Grotkiewicz, K. (2010). Miejsce i rola postepu naukowego w warunkach rolnictwa zrównoważonego. Problemy Inżynierii Rolniczej, 1, 5-12.

Obwieszczenie Ministra Rolnictwa i Rozwoju Wsi z dnia 15 grudnia 2016 r. o zmianie wykazu wymogów określonych w przepisach Unii Europejskiej z uwzględnieniem przepisów krajowych wdrażających te przepisy (M.P. 2016, pos. 1248).

Romaniuk, W., Karbowy, A. (2008). Kształtowanie warunków środowiskowych w nowoczesnych obiektach inwentarskich. Problemy Inżynierii Rolniczej, 4, 93-100.

Regulation of the Minister of Agriculture and Rural Development of 15 February 2010 on the requirements and procedure for keeping livestock species for which welfare standards have been laid down in European Union legislation (Journal of Laws [Dz. U.] no. 56, Jan 15, 2010, pos. 344).

Regulation of the Minister of Agriculture and Rural Development of 28 June 2010 on minimum conditions for keeping livestock species for which protection standards have been laid down in European Union legislation (Journal of Laws [Dz. U.], 2010, no. 116 pos. 778).

Animal Protection Act (Journal of Laws [Dz. U.] of 30 July 2013, pos. 856). 


\section{NOWOCZESNA PRODUKCJA ZWIERZECAA A DOBROSTAN}

Streszczenie. Celem pracy jest omówienie powiązań nowoczesnej produkcji zwierzęcej w tym techniki i koncentracji z wymogami dobrostanu zwierząt. Nowoczesna produkcja zwierzęca wiąże się $\mathrm{z}$ nowoczesnym budownictwem, precyzyjną produkcją zwierzęcą, intensywną i wysoką obsadą skoncentrowaną $\mathrm{w}$ jednym miejscu. Równocześnie wymaga zapewnienia zwierzętom minimalnych warunków utrzymania czyli dobrostanu określonego stosownymi przepisami. To zaś powinno dać gwarancję uzyskania dobrej jakości surowców i produktów pochodzenia zwierzęcego.

Słowa kluczowe: nowoczesna produkcja zwierzęca, dobrostan, techniczne wyposażenie, jakość 